\title{
Errata for Chemical and Pharmaceutical Bulletin
}

\begin{tabular}{|c|c|c|c|c|}
\hline Vol. & Page & Line & Error & Correction \\
\hline 57 & 87 & $\begin{array}{c} \\
\text { right } 17 \\
\text { right } 24 \\
\text { right } 25 \\
\text { right } 28-29 \\
\text { right } 1 \\
\text { right } 3 \\
\text { right } 4\end{array}$ & 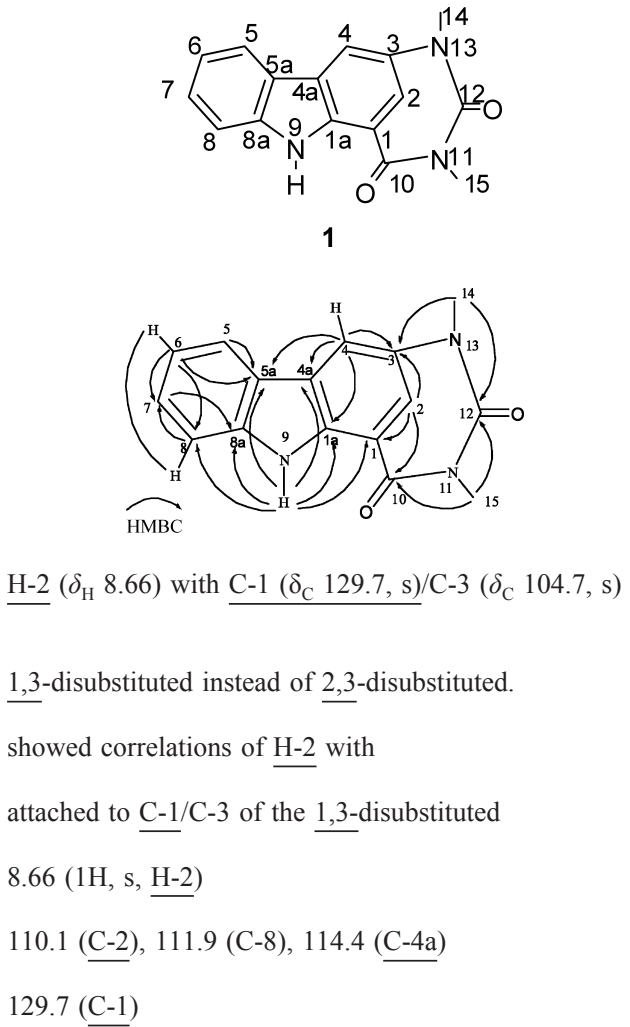 & 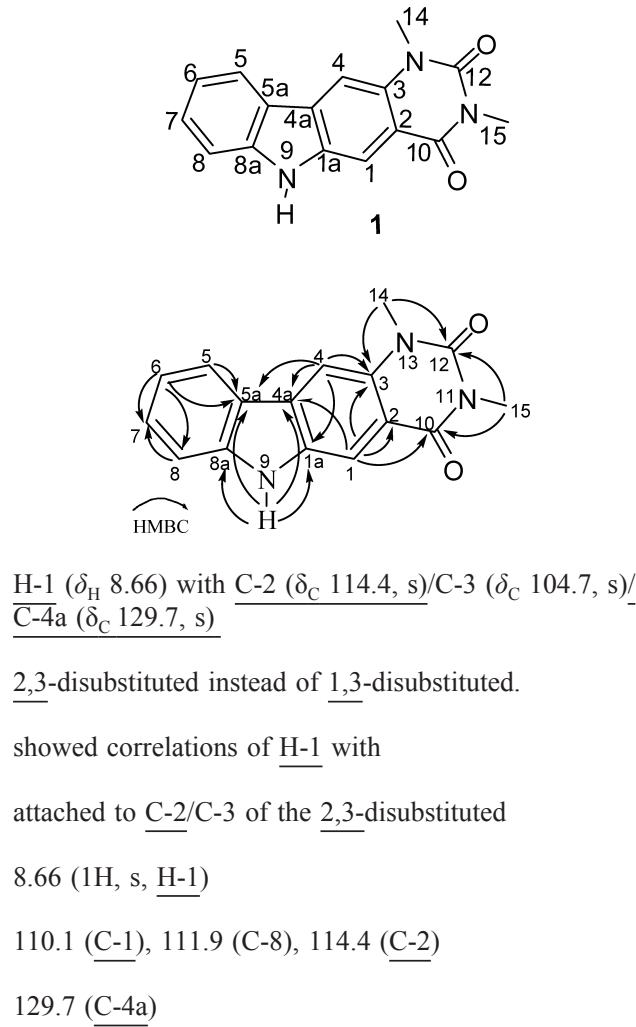 \\
\hline
\end{tabular}

